\title{
Therapeutic difficulties related to optimization of pemphigus vulgaris treatment
}

\section{Trudności terapeutyczne związane z optymalizacją leczenia pęcherzycy zwykłej}

\author{
Szymon Leonik', Emilia Karpińska', Agnieszka Owsińska', Katarzyna Sedlaczek', Beata Bergler-Czop²
}

IStudent Scientific Society at the Department of Dermatology, Medical University of Silesia, Katowice, Poland

${ }^{2}$ Department of Dermatology, Medical University of Silesia, Katowice, Poland

'Studenckie Towarzystwo Naukowe przy Katedrze i Klinice Dermatologii, Śląski Uniwersytet Medyczny w Katowicach, Polska ${ }^{2}$ Katedra i Klinika Dermatologii, Śląski Uniwersytet Medyczny w Katowicach, Polska

\author{
CORRESPONDING AUTHOR/ \\ ADRES DO KORESPONDENCJI: \\ prof. dr hab. n. med. \\ Beata Bergler-Czop \\ Katedra i Klinika Dermatologii \\ Śląski Uniwersytet Medyczny \\ ul. Francuska 20/24 \\ 40-027 Katowice \\ tel.: +4832 2561182 \\ e-mail: Bbergler-czop@sum.edu.pl
}

\begin{abstract}
A 60-year-old man with extensive erosive lesions within the scalp and face, limbs, trunk, and nasal and oral mucous membrane involvement was admitted to the ward with worsening of symptoms in the course of pemphigus vulgaris. The exacerbation took place during an attempt to reduce doses of immunosuppressive drugs and glucocorticosteroids. Additional examinations, otorhinolaryngological and dental consultation did not show another cause of this condition. Biological therapy with a monoclonal antibody directed against the CD20 antigen, rituximab, was introduced. The study presents the treatment efficacy in the patient 2 weeks after the last drug dose and compares them with the latest available knowledge on rituximab therapy in pemphigus vulgaris.
\end{abstract}

\section{STRESZCZENIE}

Sześćdziesięcioletni mężczyzna z rozległymi zmianami nadżerkowymi w obrębie owłosionej skóry głowy, a także na skórze twarzy, kończyn, tułowia, błony śluzowej nosa i jamy ustnej został przyjęty do Kliniki z powodu nasilenia objawów w przebiegu pęcherzycy zwykłej. Do zaostrzenia doszło podczas próby zmniejszenia przyjmowanych przez pacjenta dawek leków immunosupresyjnych i glikokortykosteroidów. Dodatkowe badania, konsultacja otorynolaryngologiczna i stomatologiczna nie wykazały innej przyczyny zaostrzenia. Chorego zakwalifikowano do terapii biologicznej z wykorzystaniem przeciwciała monoklonalnego skierowanego przeciwko antygenowi CD20. W pracy przedstawiono efekty leczenia pacjenta po 2 tygodniach od podania ostatniej dawki leku i zestawiono je z najnowszą dostępną wiedzą dotyczącą stosowania rytuksymabu w terapii pęcherzycy zwykłej.

Key words: rituximab, pemphigus vulgaris, bullous diseases.

Słowa kluczowe: rytuksymab, pęcherzyca zwykła, dermatozy pęcherzowe. 


\section{INTRODUCTION}

Pemphigus vulgaris is a rare, chronic, autoimmune skin disease. It is characterized by blisters within the epidermis and mucous membranes. The presence of anti-keratinocyte autoantibodies in the patient's serum is the cause of blistering lesions. Every year in the European population 1-5/million people are diagnosed with pemphigus vulgaris.

\section{OBJECTIVE}

This case report is intended to document the medical history of the patient with pemphigus vulgaris and to compare the therapeutic measures with the currently available scientific knowledge.

\section{CASE REPORT}

A 60-year-old patient was admitted to the Department of Dermatology due to exacerbation of skin lesions in the course of pemphigus vulgaris. The lesions were located on the scalp, forehead, nose, trunk and limbs. They had the form of erosions covered with crust. In addition, they were present on the mucous membranes of the mouth and throat and in the nasal vestibule. Single blistering lesions filled with serous material were located on the skin near the hip girdle (fig. 1). The first lesions appeared in March 2018, while the disease was unequivocally confirmed 5 months later by direct immunofluorescence (DIF) - pemphigus antibodies in IgG (++IC) and IgA $(+\mathrm{IC})$ classes present in the intercellular spaces throughout the epidermis. IgG antibodies of pemphigus type (IIF) were detected in the patient serum - titre: $1: 640$. Initial treatment included the use of azathioprine at a dose of $1.5 \mathrm{mg} / \mathrm{kg}$ body weight from August 2018, which was reduced to $1 \mathrm{mg} / \mathrm{kg}$ body weight in October 2018, and prednisone - initially $1 \mathrm{mg} / \mathrm{kg}$ body weight, from August $0.5 \mathrm{mg} /$ $\mathrm{kg}$ body weight; in March 2019 the prednisone dose was further reduced to $0.4 \mathrm{mg} / \mathrm{kg}$ body weight. Sudden progression of the disease occurred during an attempt to reduce the doses of glucocorticosteroids and immunosuppressive drugs.

The patient was checked for antibodies: IgG class titre $1: 320$ and IgA class negative. Laboratory tests showed elevated C-reactive protein (CRP), negative QuantiFERON-TB Gold test and low values of cancer markers (CEA, $\beta 2$-microglobulins, LDH, PSA). Other laboratory tests did not deviate from the norm. The ultrasound examination of the abdominal cavity and retroperitoneal space showed gallstones, while chest $\mathrm{X}$-ray revealed no pathological changes. Otorhinolaryngological and dental consultation excluded the occult foci of infection. Despite the intensification of

\section{WPROWADZENIE}

Pęcherzyca zwykła jest rzadką, przewlekłą chorobą autoimmunologiczną skóry. Przebiega z powstawaniem pęcherzy w obrębie naskórka i błon śluzowych. Przyczyną zmian jest występowanie w surowicy chorego autoprzeciwciał skierowanych przeciw własnym keratynocytom. Co roku pęcherzycę zwykłą rozpoznaje się u 1-5/mln osób w populacji europejskiej.

\section{CEL PRACY}

Opis przypadku ma na celu udokumentowanie historii medycznej pacjenta z pęcherzycą zwykłą oraz porównanie metod terapeutycznych $\mathrm{z}$ aktualnym stanem wiedzy naukowej.

\section{OPIS PRZYPADKU}

Sześćdziesięcioletni pacjent został przyjęty do Kliniki Dermatologii z powodu zaostrzenia zmian skórnych w przebiegu pęcherzycy zwykłej. Zmiany w postaci nadżerek pokrytych strupami były umiejscowione na owłosionej skórze głowy, a także na czole, nosie, tułowiu i kończynach. Występowały również w obrębie błon śluzowych jamy ustnej i gardła oraz w przedsionku nosa. Pojedyncze pęcherze wypełnione materiałem surowiczym stwierdzono na skórze w okolicy obręczy biodrowej (ryc. 1). Pierwsze zmiany pojawily się w marcu 2018 r., a 5 miesięcy później rozpoznanie zostało jednoznacznie potwierdzone metodą immunofluorescencji bezpośredniej (direct immunofluorescence - DIF) po wykryciu przeciwciał pęcherzycowych w klasach IgG $(++I C)$ i IgA $(+\mathrm{IC})$ w przestrzeniach międzykomórkowych w obrębie naskórka. W surowicy pacjenta wykryto przeciwciała IgG typu pęcherzycowego (IIF) w mianie 1: 640. Początkowo (od sierpnia 2018 r.) w leczeniu stosowano azatioprynę $\mathrm{w}$ dawce $1,5 \mathrm{mg} / \mathrm{kg}$ m.c., którą następnie zmniejszano do $1 \mathrm{mg} / \mathrm{kg}$ m.c. (październik $2018 \mathrm{r}$.) oraz prednizon - początkowo w dawce $1 \mathrm{mg} / \mathrm{kg}$ m.c., a następnie (od sierpnia $2018 \mathrm{r}$.) w dawce $0,5 \mathrm{mg} / \mathrm{kg}$ m.c. $\mathrm{W}$ marcu $2019 \mathrm{r}$. dawkę prednizonu zmniejszono do $0,4 \mathrm{mg} / \mathrm{kg}$ m.c. Podczas próby zmniejszenia dawek glikokortykosteroidów i leków immunosupresyjnych doszło do nagłej progresji choroby.

U chorego oznaczono przeciwciała i uzyskano miano $1: 320$ przeciwciał $w$ klasie IgG oraz ujemne miano przeciwciał w klasie IgA. Badania laboratoryjne wykazały podwyższone stężenie białka C-reaktywnego (C-reactive protein - CRP), ujemny wynik testu Quantiferon TB Gold oraz małe wartości markerów nowotworowych

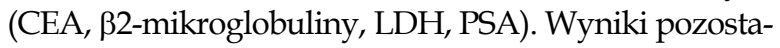
łych badań laboratoryjnych nie odbiegały od normy. W badaniu ultrasonograficznym (USG) jamy brzusznej i przestrzeni zaotrzewnowej stwierdzono kamienie żółciowe. W badaniu rentgenograficznym (RTG) klatki 

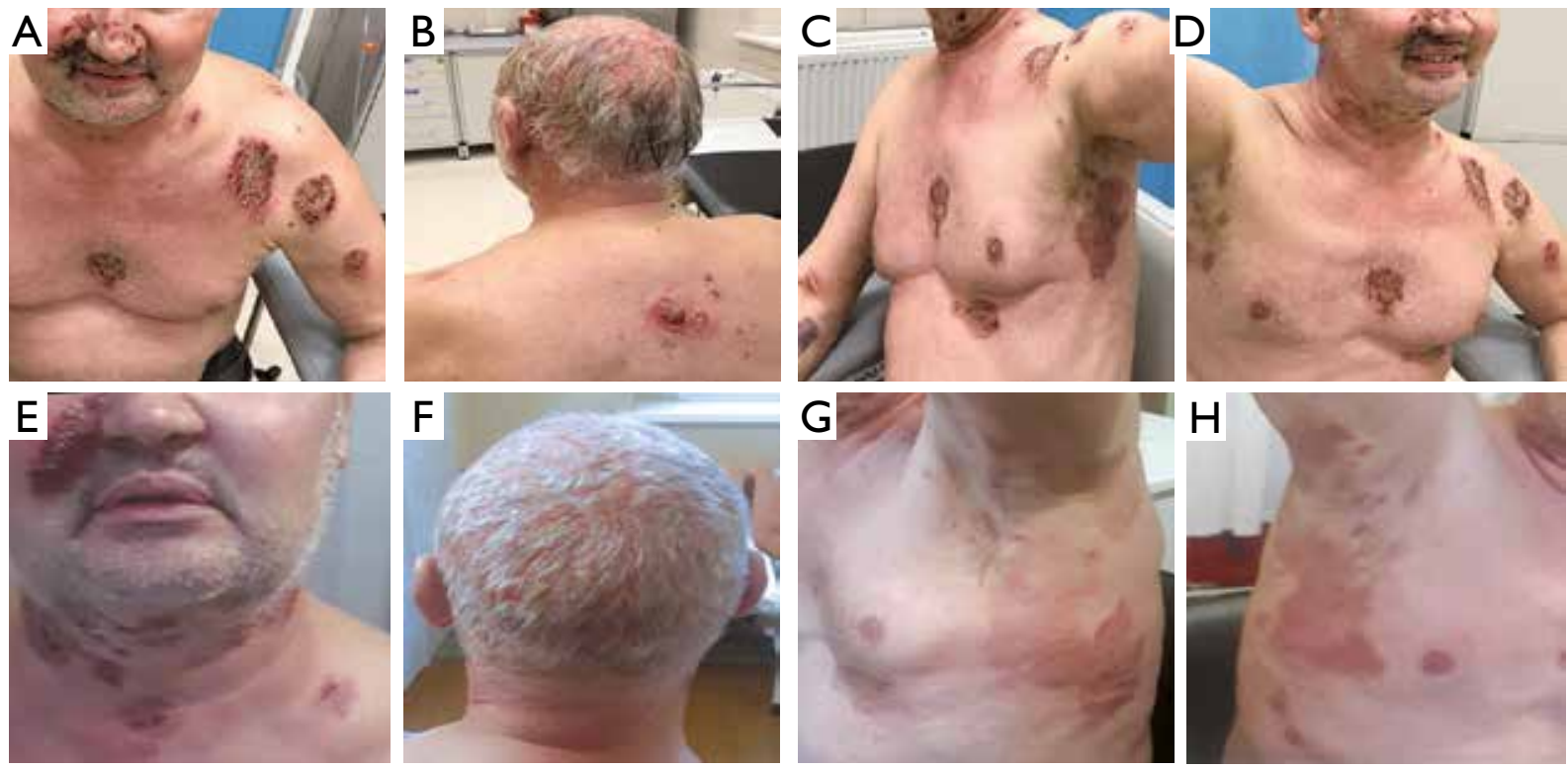

Figure I. Skin lesions before (A-D) and after two doses of biological RTX therapy $(\mathrm{E}-\mathrm{H})$

Rycina I. Zmiany skórne pacjenta przed terapią (A-D) i po dwóch dawkach terapii biologicznej RTX (E-H)

the current therapy - prednisone at a dose of $1.5 \mathrm{mg} /$ $\mathrm{kg}$ body weight, azathioprine at a dose of $1.5 \mathrm{mg} /$ $\mathrm{kg}$ body weight - further significant disease development occurred. The patient was qualified for biological treatment with rituximab (RTX) in two doses of $1 \mathrm{~g}$ each in intravenous infusion at a 14-day interval. Two weeks after the second and last drug dose the extent of skin and mucosal lesions according to the PDAI scale (table 1) was 41, while before the treatment it was 61 [1]. Significant improvement of the dermatological skin condition was observed especially in the armpit area and on the scalp. Moreover, so far no side effects of the treatment have been reported [2-4]. Currently the patient is under constant observation - prednisone dose is $0.3 \mathrm{mg} / \mathrm{kg}$ and azathioprine $100 \mathrm{mg} /$ day with a tendency to further reduction.

\section{DISCUSSION}

The clinical evaluation of RTX used during pemphigus vulgaris therapy revealed a remission in up to $73.3 \%$ of patients [2] and significant decrease in the risk of side effects during long-term glucocorticosteroid treatment [5]. There are also more arguments in the literature for the use of RTX as the first line of therapy. Patients undertaking the treatment within 6 months from the diagnosis of disease were more likely to achieve total remission than those who began the therapy at $>6$ months. Moreover, patients who began the therapy earlier had a chance to achieve long-term remission and reduce the doses piersiowej nie wykazano zmian patologicznych. Konsultacja otorynolaryngologiczna i stomatologiczna wykluczyła utajone ogniska zakażenia. Pomimo intensyfikacji dotychczasowej terapii (prednizon w dawce 1,5 mg/ kg m.c., azatiopryna w dawce $1,5 \mathrm{mg} / \mathrm{kg}$ m.c.) doszło do progresji choroby. Chorego zakwalifikowano do leczenia biologicznego rytuksymabem (RTX) w dwóch dawkach po $1 \mathrm{~g}$ we wlewie dożylnym, podawanych w odstępie 14 dni. Dwa tygodnie po podaniu drugiej i ostatniej dawki leku rozległość zmian w obrębie skóry i błon śluzowych oceniana w skali PDAI (tab. 1) wyniosła 41 punktów w porównaniu z 61 punktami przed podjęciem leczenia [1]. Zaobserwowano wyraźną poprawę stanu skóry, zwłaszcza w okolicy pach i owłosionej skóry głowy. Dotąd nie stwierdzono żadnych skutków ubocznych leczenia [2-4]. Aktualnie pacjent jest pod stałą obserwacją. Dawka prednizonu wynosi $0,3 \mathrm{mg} / \mathrm{kg}$, a dawka azatiopryny $100 \mathrm{mg} /$ dobę z planem jej dalszego zmniejszenia.

\section{OMÓWIENIE}

W ocenie skuteczności klinicznej RTX w terapii pęcherzycy zwykłej wykazano remisję u nawet $73,3 \%$ chorych [2], a także znamienne zmniejszenie ryzyka wystąpienia działań niepożądanych występujących podczas długotrwałego leczenia glikokortykosteroidami [5]. W dostępnym piśmiennictwie są też inne argumenty przemawiające za stosowaniem RTX w leczeniu pierwszego wyboru. U pacjentów podejmujących leczenie w czasie poniżej 6 miesięcy od rozpoznania choroby stwierdzono wyższe prawdopodobieństwo uzyskania całkowi- 
Table I. Pemphigus Disease Area Index developed by the International Pemphigus Definitions Group

Tabela I. Wskaźnik oceny rozległości zmian skórnych w pęcherzycy (Pemphigus Disease Area Index) opracowany przez International Pemphigus Definitions Group

\begin{tabular}{|c|c|c|c|}
\hline Skin/Skóra & Activity/Aktywność & & $\begin{array}{l}\text { Damage/Uszkodzenia } \\
\text { skóry }\end{array}$ \\
\hline \multirow{2}{*}{$\begin{array}{l}\text { Anatomical } \\
\text { location/Lokalizacja } \\
\text { anatomiczna }\end{array}$} & \multicolumn{2}{|c|}{$\begin{array}{l}\text { Erosion or blisters or new erythema/Nadżerki lub pęcherze, lub nowe zmiany } \\
\text { rumieniowe }\end{array}$} & \multirow{2}{*}{$\begin{array}{l}\text { Post-inflammatory } \\
\text { hyperpigmentation or } \\
\text { erythema from resolving } \\
\text { lesion/Przebarwienia } \\
\text { pozapalne lub rumień } \\
\text { po ustępującej zmianie } \\
\text { skórnej } \\
0 \text { - Absent/Brak } \\
\text { I - Present/Obecność }\end{array}$} \\
\hline & $\begin{array}{l}0 \text { - Absent/Brak } \\
\text { I- I-3 lesions up to one }>2 \mathrm{~cm} \text { in any diameter, none }>6 \mathrm{~cm} / \\
\text { I-3 zmiany, w tym maks. I zmiana o średnicy }>2 \mathrm{~cm} \text { w dowolnym } \\
\text { wymiarze, bez obecności zmian o średnicy }>6 \mathrm{~cm} \\
2-2-3 \text { lesions, at least two }>2 \mathrm{~cm} \text { diameter, none }>6 \mathrm{~cm} / \\
2-3 \text { zmiany, w tym co najmniej } 2 \text { zmiany o średnicy }>2 \mathrm{~cm} \text {, } \\
\text { bez obecności zmian o średnicy }>6 \mathrm{~cm} \\
3->3 \text { lesions, none }>6 \mathrm{~cm} \text { diameter } />3 \text { zmian, bez obecności } \\
\text { zmian o średnicy }>6 \mathrm{~cm} \\
5->3 \text { lesions, and } / \text { or at least one }>6 \mathrm{~cm} />3 \text { zmian i/lub co najmniej } \\
\text { I zmiana o średnicy }>6 \mathrm{~cm} \\
\text { I0- }>3 \text { lesions, and/or at least one lesion }>16 \mathrm{~cm} \text { diameter or entire } \\
\text { area/> }>3 \text { zmian i/lub co najmniej I zmiana o średnicy lub całkowitej } \\
\text { powierzchni }>16 \mathrm{~cm}\end{array}$ & $\begin{array}{l}\text { Number } \\
\text { of lesions } \\
\text { if } \leq 3 / \\
\text { Liczba } \\
\text { zmian, } \\
\text { jeśli } \leq 3\end{array}$ & \\
\hline \multicolumn{4}{|l|}{ Ears/Uszy } \\
\hline \multicolumn{4}{|l|}{ Nose/Nos } \\
\hline \multicolumn{4}{|l|}{$\begin{array}{l}\text { Rest of the face/ } \\
\text { Pozostała część twarzy }\end{array}$} \\
\hline \multicolumn{4}{|l|}{ Neck/Szyja } \\
\hline \multicolumn{4}{|l|}{ Chest/Klatka piersiowa } \\
\hline \multicolumn{4}{|l|}{ Abdomen/Brzuch } \\
\hline \multicolumn{4}{|l|}{$\begin{array}{l}\text { Back, buttocks/Plecy, } \\
\text { pośladki }\end{array}$} \\
\hline \multicolumn{4}{|l|}{ Arms/Ramiona } \\
\hline \multicolumn{4}{|l|}{ Hands/Ręce } \\
\hline \multicolumn{4}{|l|}{ Legs/Nogi } \\
\hline \multicolumn{4}{|l|}{ Feet/Stopy } \\
\hline \multicolumn{4}{|l|}{$\begin{array}{l}\text { Genitals/Okolica } \\
\text { narządów ptciowych }\end{array}$} \\
\hline $\begin{array}{l}\text { Total skin/Całkowita } \\
\text { powierzchnia skóry }\end{array}$ & $/ 120$ & & $/ 12$ \\
\hline \multicolumn{4}{|c|}{ Scalp/Owłosiona skóra głowy } \\
\hline $\begin{array}{l}\text { Scalp/Owłosiona skóra } \\
\text { głowy }\end{array}$ & $\begin{array}{l}\text { Erosion or blisters or new erythema/Nadżerki lub pęcherze, lub } \\
\text { nowe zmiany rumieniowe } \\
0 \text { - Absent/Brak } \\
\text { I - In one quadrant/W I kwadrancie } \\
2 \text { - Two quadrants } \mathrm{W} 2 \text { kwadrantach } \\
3 \text { - Three quadrants/W } 3 \text { kwadrantach } \\
4 \text { - Affects whole skull/Cała skóra czaszki } \\
\text { I0 - At least one lesion }>6 \mathrm{~cm} / \text { Co najmniej jedna zmiana } \\
\text { o wielkości }>6 \mathrm{~cm}\end{array}$ & $\begin{array}{l}\text { Liczba } \\
\text { zmian jeśli } \\
\leq 3 / \text { Liczba } \\
\text { zmian, } \\
\text { jeśli } \leq 3\end{array}$ & $\begin{array}{l}\text { Post-inflammatory } \\
\text { hyperpigmentation or } \\
\text { erythema from resolving } \\
\text { lesion/Przebarwienia } \\
\text { pozapalne lub rumień } \\
\text { po ustępującej zmianie } \\
\text { skórnej } \\
0 \text { - Absent/Brak } \\
\text { I - Present/Obecność } \\
(0-10) / 10 / I\end{array}$ \\
\hline
\end{tabular}

Total scalp
$(0-10) /$ Całkowita

powierzchnia

owłosionej skóry

głowy (0-10) 
Table I. Cont.

Tabela I. Cd.

Mucous membrane/Błony śluzowe

Anatomical

location/Lokalizacja

anatomiczna

\begin{tabular}{ll} 
Erosion or blisters/Nadżerki lub pęcherze & \\
\hline $0-$ Absent/Brak & Number \\
$1-$ I lesion/I zmiana & lesions \\
$2-2-3$ lesions/2-3 zmiany & if $\leq 3 /$ \\
$5->3$ lesions or 2 lesions $>2 \mathrm{~cm} />3$ zmiany lub 2 zmiany & Liczba \\
O wielkości $>2 \mathrm{~cm}$ & zmian, \\
$10-$ Entire area/Cała powierzchnia & jeśli $\leq 3$
\end{tabular}

Eyes/Oczy

Nose/Nos

Buccal muc osa/Błona

śluzowa policzków

Hard palate/

Podniebienie twarde

Soft palate/

Podniebienie miękkie

Upper gingival/Dziąsła

górne

Lower gingival/Dziąsła

dolne

Tongue//ęzyk

Floor of mouth/Dno

jamy ustnej

Labial muc osa/Błona

śluzowa warg

Posterior pharynx/

Tylna część gardła

Anogenital/Okolica

odbytu i narządów

płciowych

Total mucosa/Całkowita

powierzchnia błon

śluzowych

\begin{tabular}{ll}
\hline Total activity score/ & Total damage score/ \\
Łączny wynik - aktywność: & Łączny wynik - uszkodzenie skóry:
\end{tabular}

of complementary therapy $[3,4,6,7]$. Other studies have shown that the use of RTX treatment combined with short-term prednisolone as a first-line therapy is more effective in achieving complete remission but also safer than treatment with prednisolone alone [6, 8-10].

\section{CONCLUSIONS}

The presented case and scientific reports confirm the effectiveness of RTX. The provided evidence may change the current therapeutic recommendations of pemphigus vulgaris and allow for earlier therapy with monoclonal antibodies.

\section{CONFLICT OF INTEREST}

The authors declare no conflict of interest. tej remisji niż u chorych, którzy rozpoczęli terapię po 6 miesiącach od rozpoznania. Ponadto pacjenci, którzy wcześniej rozpoczęli leczenie, mieli szansę na osiągnięcie długotrwałej remisji i zmniejszenie dawek leków stosowanych w ramach terapii uzupełniającej $[3,4,6,7]$. $\mathrm{W}$ innych badaniach wykazano, że terapia pierwszego wyboru obejmująca RTX w skojarzeniu z krótkim cyklem leczenia prednizolonem jest skuteczniejsza pod względem uzyskania całkowitej remisji, a także bezpieczniejsza $\mathrm{w}$ porównaniu $\mathrm{z}$ prednizolonem stosowanym $\mathrm{w}$ monoterapii $[6,8-10]$.

\section{WNIOSKI}

Przedstawiony przypadek oraz dostępne doniesienia naukowe potwierdzają skuteczność terapeutyczną RTX w omawianym wskazaniu. Dostępne dowody mogą się przyczynić do zmiany dotychczasowych zaleceń terapeutycznych w pęcherzycy zwykłej i umożliwić 
wcześniejsze podejmowanie leczenia przeciwciałami monoklonalnymi.

\section{KONFLIKT INTERESÓW}

Autorzy nie zgłaszają konfliktu interesów.

\section{References}

\section{Piśmiennictwo}

1. Murrell D.F., Dick S., Ahmed A.R., Amagai M., Barnadas M.A., Borradori L., et al.: Consensus statement on definitions of disease, end points, and therapeutic response for pemphigus. J Am Acad Dermatol 2008, 58, 1043-1046.

2. De D., Bishnoi A., Handa S., Mahapatra T., Mahajan R.: Effectiveness and safety analysis of rituximab in 146 Indian pemphigus patients: a retrospective single-center review of up to 68 months follow-up. Indian J Dermatol Venereol Leprol 2020, $86,39-44$.

3. Anandan V., Jameela W.A., Sowmiya R., Mani Surya Kumar M., Lavanya P.: Rituximab: a magic bullet for pemphigus. J Clin Diagn Res 2017, 11, WC01-WC06.

4. Cho H.H., Jin S.P., Chung J.H.: Clinical experiences of different dosing schedules of rituximab in pemphigus with various disease severities. J Eur Acad Dermatol Venereol 2014, 28, 186-191.

5. Laftah Z., Craythorne E., Mufti G.J., du Vivier A.: Clinical efficacy of rituximab in the treatment of pemphigus vulgaris: a 10year follow-up. J Oral Pathol Med 2019, 48, 861-862.

6. Vinay K., Dogra S.: Rituximab in pemphigus: road covered and challenges ahead. Indian Dermatol Online J 2018, 9, 367-372.

7. Balighi K., Daneshpazhooh M., Mahmoudi H., Badakhsh M., Teimourpour A., Ehsani A.H., et al.: Comparing early and late treatments with rituximab in pemphigus vulgaris: which one is better? Arch Dermatol Res 2019, 311, 63-69.

8. Joly P., Maho-Vaillant M., Prost-Squarcioni C., Hebert V., Houivet E., Calbo S., et al.: First-line rituximab combined with short-term prednisone versus prednisone alone for the treatment of pemphigus (Ritux 3): a prospective, multicentre, parallel-group, open-label randomised trial. Lancet 2017, 389, 2031-2040.

9. Ahmed A.R., Shetty S.: A comprehensive analysis of treatment outcomes in patients with pemphigus vulgaris treated with rituximab. Autoimmun Rev 2015, 14, 323-331.

10. Chen D.M., Odueyungbo A., Csinady E., Gearhart L., Lehane P., Cheu M., et al.: Rituximab is an effective treatment in patients with pemphigus vulgaris and demonstrates a steroid-sparing effect. Br J Dermatol 2020, 182, 1111-1119.

Received: 18.03 .2020

Accepted: 14.08 .2020

Otrzymano: $18.03 .2020 \mathrm{r}$

Zaakceptowano: $14.08 .2020 \mathrm{r}$. 